\title{
Badanie sprawności gramatycznej w normie i zaburzeniach mowy - przegląd stanowisk
}

\section{Assessing grammar skills within normal range and in speech disorders - opinions}

\author{
Jolanta Panasiuk \\ Uniwersytet Marii Curie-Skłodowskiej, Zakład Logopedii i Językoznawstwa Stosowanego, Lublin
}

Adres autora: Jolanta Panasiuk, Uniwersytet Marii Curie-Skłodowskiej, Zakład Logopedii i Językoznawstwa
Stosowanego, ul. J. Sowińskiego 17, 20-040 Lublin, e-mail: lisa@poczta.onet.eu

\begin{abstract}
Streszczenie
Sprawność gramatyczna jest elementem sprawności systemowej, warunkującej rozumienie i używanie znaków i reguł systemu językowego i odnosi się do sposobu łączenia słów w znaczące frazy i zdania. W logopedii problem sprawności gramatycznej powiązany jest z potrzebą diagnozowania zaburzeń mowy oraz programowania terapii logopedycznej u dzieci, u których ta sprawność nie wykształciła się, oraz u dorosłych, u których uległa rozpadowi. Istniejące narzędzia do oceny sprawności gramatycznej $\mathrm{u}$ dzieci w wieku rozwojowym i u dorosłych $\mathrm{z}$ nabytymi zaburzeniami mowy w przebiegu schorzeń neuropsychiatrycznych są niewystarczające do systemowej oceny sposobu rozumienia i realizowania wzorców składniowych i wykładników wszystkich kategorii fleksyjnych. Jedynie pełna ocena stanu sprawności gramatycznych może stanowić podstawę programowania ćwiczeń językowych, dobranych zgodnie ze stopniem i zakresem istniejącego deficytu gramatycznego u poszczególnych pacjentów.
\end{abstract}

Słowa kluczowe: ontogeneza mowy $\bullet$ zaburzenia mowy • fleksja $\bullet$ składnia $\bullet$ agramatyzm

\begin{abstract}
Grammar skills are system skills that determine the understanding and use of signs and rules of the language system They consist in combining words into meaningful phrases and sentences. In speech therapy the problem of grammar skills causes the need to diagnose speech disorders and to program logopedic treatment in children whose grammar skills have not developed and in adults who lost those skills. The existing tools used to assess grammar skills in children of developmental age and in adults with speech disorders acquired due to neuropsychiatric diseases are insufficient to systemically assess the way of understanding and production of syntactic patterns and exponents of all inflectional categories. Only a complete assessment of grammar skills can be the basis for programming language exercises selected in accordance with the degree and extent of the existing grammar deficit in individual patients.
\end{abstract}

Key words: speech ontogeny $\bullet$ speech disorders • inflection • syntax • agrammatism

Sprawność gramatyczna jako element językowej sprawności systemowej

W realizacji czynności mowy każdego człowieka ujawniają się osobne aspekty wiedzy wchodzące w zakres zachowań społecznych (wspólnych) i indywidualnych. W obręb zachowań wspólnych Stanisław Grabias $[1,2]$ włącza:

1) kompetencję językową (inwentarz fonemów, leksemów oraz reguły budowania gramatycznie poprawnych i sensownych zdań), na którą składa się kompetencja fonologiczna, morfologiczna i składniowa,

2) kompetencję komunikacyjną (wiedzę na temat statusu kodów językowych i na temat reguł budowania wypowiedzi odpowiednich do sytuacji), na którą składa się kompetencja stylistyczna, społeczna, sytuacyjna i pragmatyczna,

3) kompetencję kulturową (wiedzę na temat otaczającej rzeczywistości, systemu wartości obowiązującego w danej kulturze oraz interpretacji zjawisk będącej efektem tkwiącej w języku potocznej wiedzy o świecie).

Warunkiem nabycia zarówno kompetencji kulturowej, jak i komunikacyjnej jest dysponowanie systemem językowym. Wszystkie zaś typy kompetencji urzeczywistniają się w indywidualnych zachowaniach językowych dzięki umiejętnościom, które Grabias [2] określa sprawnościami. Realizację kompetencji językowej umożliwia sprawność systemowa. 
Sprawność systemowa definiowana jest jako umiejętność budowania zdań gramatycznie poprawnych. W jej obrębie mieści się grupa sprawności, które stanowią o fizycznym kształcie wypowiedzi. Należą do nich:

1) sprawności substancjalne (pozwalające realizować wypowiedzi w postaci sygnałów akustycznych, optycznych i taktylnych, czyli dotykowych);

2) sprawności gramatyczne (morfologiczne, syntaktyczne - dotyczą umiejętności operowania morfemami, wyrazami i zdaniami) ${ }^{1}$.

Opanowanie tych sprawności warunkuje zdolność do realizowania wypowiedzi w danym języku. Język polski należy do grupy języków fleksyjnych, jego gramatyka opiera się na dwóch kategoriach morfologicznych:

1) werbalne (predykatywowe) - czas, aspekt, tryb, strona, osoba,

2) imienne - przypadek, liczba, rodzaj gramatyczny.

Wykładnikami kategorii morfologicznych są końcówki fleksyjne, czyli morfemy występujące jako ostatnie w ciągu morfemów tworzących formę fleksyjną wyrazu. Każdy z nich - rozumiany jako abstrakcyjna jednostka systemu językowego - posiada określoną formę fonologiczną i treść (funkcję, znaczenie). Morfemy fleksyjne tworzą odmienne formy wyrazów i wyrażają jakąś kategorię gramatyczną, a wraz z tematem fleksyjnym, który ujmuje znaczenie leksykalne jednostki wyrazowej, budują szkielet wyrazów. Postać fonologiczna tematu fleksyjnego, do którego przyłączana jest końcówka fleksyjna, bywa rozmaita:

- może być we wszystkich formach wyrazu identyczna,

- może zawierać tzw. alternacje morfonologiczne (wymiany morfemów zachodzące w obrębie jednego morfemu, uwarunkowane kontekstem),

- formy fleksyjne wyrazu mogą opierać się na dwu obocznych tematach fleksyjnych,

- może wystąpić supletywizm tematu fleksyjnego (niepowtarzalne jednostkowe oboczności postaci tematu) [3].

Wykładniki fleksyjne wyrazów są w języku polskim bardzo zróżnicowane. Sama odmiana rzeczownika (deklinacja) operuje 112 końcówkami (30 końcówek w rodzaju męskim, 29 - w żeńskim, 53 - w nijakim), a każdą końcówką rządzi odrębna reguła gramatyczna. Zestaw tych reguł należy jeszcze uzupełnić o reguły morfonologiczne, które określają fonetyczną postać tematu fleksyjnego w przypadkach zależnych (np. pies: psa, kot: kocie) [4]. W opisie sprawności gramatycznej uwzględnić ponadto należy imiesłowy jako formy czasownika (ich stosowanie przysparza szczególnych trudności) oraz kategorię stopnia przymiotników i przysłówków.

Znacząca trudność w opisie zaburzeń rozwoju sprawności gramatycznych oraz ich rozpadu, a także stworzeniu narzędzi do ich badania wiąże się też z tym, że przykłady dokumentujące zaburzenia gramatycznej strony języka nie poddają się jednoznacznej kwalifikacji w obrębie pojedynczych kategorii fleksyjnych ze względu na współfunkcyjność oraz wielofunkcyjność końcówek fleksyjnych. Stąd niektóre niepoprawne formy wyrazu tekstowego należy rozpatrywać jako przejawy zakłóceń w obrębie dwu lub więcej kategorii gramatycznych. Problem sprawności gramatycznych dotyczy również budowy wypowiedzeń ${ }^{2}$. Wypowiedzenia mogą mieć różne postaci, podstawową ich formą jest pełne zdanie, a więc konstrukcja zawierająca predykatywną formę czasownika. Wypowiedzenia niezawierające osobowej formy czasownika to równoważniki zdań (oznajmienia kontekstowe i samoistne), natomiast wyrażenia przekazujące informację wespół z całą sytuacją, a zwłaszcza obiektem, który określają, to zawiadomienia [5].

Każde empiryczne zdanie zawiera w sobie swego rodzaju szkielet konstrukcyjny oparty na wymaganiach semantyczno-składniowych użytego w nim czasownika. Wypowiedzenie nie jest więc prostym połączeniem składników, ale konstrukcją wielopoziomową, w ramach której nawarstwia się swoista hierarchia konstrukcji syntaktycznych grup o różnym stopniu złożoności. Poszczególne pozycje składniowe, wymagane przez czasownik, mogą być w konkretnym zdaniu mniej lub bardziej rozwinięte (czasem wyzerowane). Schematy zdaniowe są więc pewnymi abstraktami, można je zdefiniować jako modelowy układ pozycji składniowych wyznaczany przez właściwości konotacyjne (semantyczno-składniowe) czasowników ${ }^{3}$ [6]. Funkcjonowanie wewnętrznych wzorców składniowych umożliwia - zdaniem psycholingwistów ${ }^{4}$ - poprawne formułowanie wypowiedzeń, ich korygowanie, jeśli zawierają błędy, a także rozumienie treści słyszanych zdań $[7,8]$. Nieprawidłowości w realizacji gramatycznych postaci wyrazów i zdań określa się mianem „agramatyzmu”.

\footnotetext{
1. W systemie języka wyraz jest jednocześnie częścią składową nadrzędnego kontekstu - zdania, a także kontekstem nadrzędnym wobec składników podrzędnych - morfemów i fonemów. Każdy element może wystąpić w olbrzymiej liczbie konstrukcji syntaktycznych różniących się między sobą typem związków syntaktycznych i semantycznych [3].

2. Wskazując na konkretne, empiryczne zdanie, należy mieć na myśli nie jednostkowe okazy, ale ich typy - wypowiedzenia, które stanowią najmniejszy odcinek tekstu będący samodzielnym komunikatem. Owa samodzielność informacyjna wypowiedzeń przejawia się w zamkniętej intonacji - w tekstach pisanych jej wykładnikiem jest znak graficzny (kropka, wykrzyknik, znak zapytania).

3. Dostosowywanie się do siebie jednostek językowych w zdaniu określa się terminem „akomodacja syntaktyczna” (od łac. accomodare - przystosowywać). Dostosowanie to polega najczęściej na przyjmowaniu konkretnych wartości kategorii gramatycznych (takich jak rodzaj, liczba i przypadek) przez jednostkę wchodzącą w konstrukcję z inną jednostką. Jest to tzw. „akomodacja syntaktyczna morfologiczna”. Oprócz tego wyróżnia się także „akomodację niemorfologiczną”: słownikową, polegającą na wymaganiu określonego leksemu, np. przyimka, oraz „akomodację składniową", czyli wymaganie określonej konstrukcji składniowej, np. zdania rozpoczynającego się od konkretnego spójnika [9].

4. Mechanizm powstawania zakłóceń języka na poziomie składniowym w duchu psycholingwistyki przedstawił Z. Klemensiewicz: „Od myślowego tworzywa zdania, ujmowanego szkicowo, prowizorycznie i płynnie w mowie wewnętrznej, do gotowego zdania gramatycznego mowy zewnętrznej prowadzi operacja zdaniotwórcza. Polega ona na poszukiwaniu i wyborze odnośnego, a najodpowiedniejszego, znaku językowego dla każdego składnika tworzywa zdaniowego, dla każdego związku i stosunku jego składników” [10: 177].

5. W Słowniku języka polskiego pod red. W. Doroszewskiego przymiotnik , agramatyczny” wyjaśniony jest jako: 'pozbawiony związków gramatycznych', podobnie w Stowniku wyrazów obcych pod red. J. Tokarskiego nazwy „agramatyzm” i „agramatyczny” określają błędne budowanie zdań i niezdolność do tworzenia poprawnych form gramatycznych, odnosząc obydwa terminy do językowych kryteriów poprawnościowych.
} 


\section{Agramatyzmy w zaburzeniach mowy}

Zaburzenia w budowaniu zdań traktowane są jako jeden z podstawowych objawów zaburzeń mowy. W przypadku zaburzeń rozwoju językowego stanowią centralny deficyt syntaktyczny, w przeciwieństwie do przypadków rozpadu sprawności językowych, kiedy są skutkiem zaburzenia procesów syntaktycznych i powinny być interpretowane $\mathrm{w}$ odniesieniu do psycholingwistycznego modelu planowania zdania ${ }^{6}$. Trudności w opanowaniu sprawności gramatycznych dotyczą osób, u których ograniczenia natury biologicznej (głuchota, upośledzenie umysłowe, całościowe zaburzenia rozwojowe, uszkodzenia i dysfunkcje mózgu i in.) uniemożliwiają opanowanie kompetencji językowej. Utrata sprawności gramatycznych cechuje przede wszystkim osoby $\mathrm{z}$ afazją, chociaż nieprawidłowości w rozumieniu struktur składniowych, a także zakłócenia formalnej i semantycznej organizacji zdania mogą wystąpić $\mathrm{w}$ innych nabytych schorzeniach neuropsychiatrycznych, $\mathrm{np}$. w schizofrenii czy w chorobach neurodegeneracyjnych.

\section{Badanie zaburzeń rozwoju sprawności gramatycznej}

Objawy zaburzeń rozwoju sprawności systemowej na poziomie morfologicznym i składniowym dotyczą trudności $\mathrm{w}$ tworzeniu form fleksyjnych oraz rozumienia i tworzenia struktur składniowych ${ }^{7}$. Ocenę stanu sprawności gramatycznej dziecka w okresie rozwojowym przeprowadza się przy użyciu kwestionariuszy, prób eksperymentalno-klinicznych, skal i testów. Badanie powinno obejmować czynności rozumienia i tworzenia struktur składniowych o różnej budowie, w których występują rozmaite wykładniki kategorii fleksyjnych (deklinacyjnych i koniugacyjnych). Wyniki badania należy interpretować w kontekście norm rozwojowych ${ }^{8}$.

Analiza materiału językowego prowadzona jest według kryteriów lingwistycznych, które obejmują odpowiedź na pytania dotyczące następujących kwestii $[13,14]$ :

1. Jaki rodzaj wypowiedzi tworzy dziecko?

1.1. jednoklasowe (strzępkowe; jednosymbolowe; wielosymbolowe),

1.2. dwuklasowe (przejściowe; pełne - zdanie, równoważnik; eliptyczne);

2. Jaki rodzaj struktur składniowych tworzy dziecko?
2.1. związki (orzekające; określające - zgody, rządu, przynależności),

2.2. rodzaje wypowiedzeń:

- $\quad$ ze względu na znaczenie (oznajmujące, pytające, rozkazujące, wykrzyknikowe),

- ze względu na formę (zdanie; równoważnik zdania),

- ze względu na budowę (pojedyncze - rozwinięte, nierozwinięte; złożone - współrzędnie, podrzędnie);

3. Czy dziecko używa cytatu?

4. Jakie osobliwości językowe występują w wypowiedziach dziecka?

4.1. opuszczanie zaimka zwrotnego,

4.2. pomieszanie kategorii osoby, rodzaju, liczby,

4.3. zmiana szyku zdania;

5. Jak dziecko realizuje kategorie gramatyczne?

5.1. deklinacyjne,

5.2. koniugacyjne.

W logopedycznej ocenie stanu sprawności gramatycznych stosuje się przede wszystkim narzędzia nieznormalizowane, niebędące testami, które umożliwiają rozpoznanie nieprawidłowości w rozwoju językowym w celu zapewnienia wczesnej opieki logopedycznej. Do takich należy m.in. Badanie przesiewowe do wykrywania zaburzeń rozwoju mowy u dzieci dwu-, cztero- $i$ sześcioletnich [15], obejmujące zadania dotyczące rozumienia poleceń słownych i zdolności do wypowiadania się. Dane uzyskiwane są na podstawie wywiadu $\mathrm{z}$ rodzicami lub opiekunami dziecka oraz rejestrowania wypowiedzi dziecka w czasie zabawy. Obserwację werbalnych i niewerbalnych zachowań dziecka w sytuacji zaaranżowanej przy użyciu materiałów obrazkowych umożliwia również Afa-skala. Jak badać mowę dziecka afatycznego [16]. Podobnie dość orientacyjną ocenę stanu sprawności gramatycznych dzieci w wieku 3-6 lat umożliwia Test do badań przesiewowych mowy dzieci w wieku przedszkolnym [17], który de facto nie jest testem, lecz kwestionariuszem. Znacznie szerszy zakres badania zawiera Całościowe badanie logopedyczne $z$ materiałem obrazkowym [18], w którym próby do oceny sprawności gramatycznej obejmują: tworzenie i rozumienie wypowiedzi, w tym rozumienie tekstu kilkuzdaniowego, zdań (poleceń) prostych i złożonych, a także ocenę form fleksyjnych (użycie oraz rozumienie form liczby pojedynczej i mnogiej rzeczowników i czasowników, użycie form przypadków rzeczownika (dodatkowo w połączeniu z przymiotnikiem) oraz rozumienie i tworzenie konstrukcji

\footnotetext{
6. Badanie sprawności gramatycznej na potrzeby diagnozy i terapii logopedycznej wymaga przyjęcia jednej spośród dwu teorii językowych: strukturalizmu [11] lub gramatyki generatywnej [12]. Przyjmując za strukturalizmem pojęcie systemu językowego i wydzielając trzy poziomy jego organizacji - fonologiczny, morfologiczny i składniowy, sprawność gramatyczną należy badać poprzez ocenę sposobu realizacji kategorii fleksyjnych i struktur składniowych. Natomiast przyjmując założenia gramatyki generatywno-transformacyjnej, sprawność gramatyczną należy oceniać poprzez zdolność do budowania zdań i przeprowadzania operacji formalnych na zdaniu.

7. U dzieci z zaburzeniami rozwoju sprawności gramatycznych następuje redukcja fleksyjnego nacechowania wypowiedzi - dziecko zestawia wyrazy w formach podstawowych lub nieprawidłowo je odmienia w obrębie wszystkich kategorii deklinacyjnych i koniugacyjnych, rzadko używa wyrazów gramatycznie lub semantycznie niesamodzielnych, np. przyimków - często zestawienie przyimka z rzeczownikiem będące całostką akcentową stanowi dla dziecka jeden wyraz. Trudności w rozpoznawaniu relacji gramatycznych pomiędzy strukturami języka uniemożliwiają prawidłowe rozumienie komunikatów słownych. W związku z ograniczeniami gramatycznymi i składniowymi dzieci nie tworzą spójnych formalnie, semantycznie i pragmatycznie struktur monologowych zgodnie z normami rozwojowymi, lepiej natomiast funkcjonują w realizacji form dialogowych - ich wypowiedzi są zwykle krótkie, najczęściej stanowią ciąg kilku słów połączonych związkiem sytuacyjnym [14].

8. Wiele wątpliwości interpretacyjnych może wiązać się z naruszeniem gramatycznej spójności tych tekstów, które nie są znakiem zaburzeń rozwojowych, ale cechą wypowiedzi mówionych w normie rozwojowej. Inną trudnością w analizie wypowiedzi spontanicznych jest kryterium segmentacji tekstu mówionego na jednostki składniowe. Zwykle jako wyznaczniki granicy zdań przyjmuje się czynniki prozodyczne: intonację, akcent czy pauzę fonetyczną. Dodatkowo o sposobie delimitacji wypowiedzi i wyodrębniania całostek składniowych może decydować kryterium semantyczno-logiczne.
} 
fleksyjnych. Wymienione narzędzia służą ocenie jakościowej, w której diagnosta dokonuje oceny poziomu rozwoju sprawności gramatycznych, odwołując się do własnej wiedzy i doświadczenia. Brak odniesienia wyników badania pojedynczego dziecka do badań populacyjnych może utrudniać interpretację materiału językowego i orzekanie o ewentualnych nieprawidłowościach rozwojowych [19].

Istotną trudnością w obiektywizowaniu badania stanu sprawności gramatycznej dziecka w normie rozwojowej i z zaburzeniami rozwoju mowy jest niedostatek wystandaryzowanych narzędzi diagnostycznych, niezbędnych do przeprowadzenia tzw. diagnozy unormowanej'. Jako znormalizowane narzędzia do oceny poziomu rozwoju sprawności językowych, w tym gramatycznych, wymienić należy [20]:

1. techniki selekcyjne (przesiewowe),

2. techniki zasadnicze.

Te pierwsze służą szybkiemu wyselekcjonowaniu dzieci z zaburzeniami mowy, pozwalają wskazać na dzieci ze znacznie obniżonymi wynikami badania ${ }^{10}$. Mogą być stosowane przez logopedów, ale są też wykorzystywane przez innych specjalistów oceniających rozwój dziecka, m.in. pedagogów, psychologów, foniatrów, audiologów, pediatrów. Natomiast testy zasadnicze pozwalają na kompleksową ocenę poziomu i profilu umiejętności językowych, stanowiącą jedną z przesłanek do postawienia rozpoznania logopedycznego i podstawę do zaprogramowania optymalnego programu terapii logopedycznej.

W Polsce niewiele jest narzędzi służących mierzeniu sprawności językowych dzieci w okresie rozwojowym. Do technik selektywnych zaliczyć należy Przesiewowy Test Logopedyczny [21], znormalizowany na próbie 1000 zdrowych dzieci w wieku od 4.0 do 8.11 roku życia, który obok prób oceniających artykulację, zasób słownikowy oraz rozumienie podstawowych pojęć zawiera też zadania mające na celu ocenę sprawności w budowaniu zdań. Wśród narzędzi do badań przesiewowych oceniających m.in. sprawności gramatyczne w grupie dzieci starszych plasuje się znormalizowany Logopedyczny Test Przesiewowy dla Dzieci $w$ Wieku Szkolnym [22]. Przy użyciu tego narzędzia logopeda może w stosunkowo krótkim czasie przebadać dużą grupę dzieci i sprawdzić ich kompetencję językową, komunikacyjną i kulturową w kontekście oceny sprawności realizacyjnych i percepcyjnych. Test umożliwia ocenę stanu rozwoju mowy i ewentualną kwalifikację do dalszej diagnozy logopedycznej. Narzędzie zostało wystandaryzowane w grupie 1800 dzieci w wieku 6-14 lat. Badanie obejmuje cztery podtesty, a ocena wykonania zadań uwzględnia zdolność realizowania przez dziecko wypowiedzi zgodnie $\mathrm{z}$ formalnymi regułami systemu językowego.

Badanie przesiewowe przeznaczone do oceny sprawności językowych uczniów kończących szkołę podstawową, uczniów gimnazjów oraz osób dorosłych w związku z kwalifikacją do klas językowych oraz prognozowaniem opanowania języka obcego prowadzone jest przy użyciu Testu Zdolności Językowych [24]. Struktura narzędzia obejmuje trzy części, gdzie obok skali gramatycznej oceniającej umiejętność rozpoznawania budowy słów i zdań, znajduje się skala do oceny dyskursu, mierząca umiejętność operowania tekstem jako całością, a także skala do oceny słownictwa, mierząca zasób słów, form znaczeniowych oraz umiejętność ich wykorzystania w tekście.

Metrycznym narzędziem kompleksowo oceniającym sprawności językowe, w tym gramatyczne, dzieci w wieku 4-8 lat jest Test Sprawności Językowej [25]. Test został znormalizowany i wystandaryzowany na grupie 1000 dzieci ze wsi i miast. Badanie obejmuje siedem skal umożliwiających ocenę sprawności gramatycznych, w tym rozumienia dłuższych wypowiedzi i rozumienia struktur składniowych, znajomości reguł gramatycznych i umiejętności budowania zdań (zadawanie pytań, formułowanie próśb i poleceń) oraz umiejętności odtwarzania wysłuchanego tekstu ${ }^{11}$. Narzędzie może być stosowane do pomiaru wiedzy leksykalnej, gramatycznej (składniowej i fleksyjnej) oraz dyskursywnej i wykorzystywane do diagnozy, programowania i ukierunkowania terapii, a także do oceny efektów prowadzonych działań naprawczych.

Celom eksperymentalnym służą rozbudowane narzędzia psychometryczne, do których należą: Heidelberger Sprachentwicklungstest (HSET) ${ }^{12}$, Preschool Language Assesment Instrument (PLAI) ${ }^{13}$ oraz Standaryzowane Narzędzie do Oceny Wypowiedzi (SNOW) [26]. Test HSET służy do badania kompetencji i sprawności językowych u dzieci między 3 a 9 rokiem życia. Zadania sprawdzające poziom rozwoju językowego podzielone są na dwie grupy: łatwiejsze (przeznaczone dla dzieci do 5 r.ż.) i trudniejsze (dla dzieci w przedziale wiekowym 5-9 lat). Znajomość reguł gramatycznych w tym teście jest oceniana na podstawie następujących zadań: rozumienia struktur gramatycznych (różnicowanie podmiotu i obiektu), tworzenia liczby pojedynczej i mnogiej rzeczowników, powtarzania zdań, tworzenia wyrazów pochodnych według wskazanych kategorii

\footnotetext{
9. Znormalizowane i wystandaryzowane testy psychometryczne służące do oceny kompetencji językowej dzieci są dostępne na świecie od lat 80. ubiegłego wieku. Testy te w większości zostały opracowane w USA, w związku z czym odwołują się do norm ustalonych dla osób, których pierwszym językiem jest język angielski.

10. Badania przesiewowe są szczególnie ważne w okresie przedszkolnym, kiedy dzieci mające rozmaite doświadczenia językowe i zróżnicowaną dynamikę dotychczasowych osiągnięć zostają postawione wobec zunifikowanych wymogów. W tych okolicznościach mogą ujawniać się nawet dyskretne nieprawidłowości, niezauważone wcześniej w środowisku rodzinnym i trudne do dostrzeżenia w orientacyjnym badaniu mowy [23].

11. Opanowanie zasad gramatycznych jest oceniane w tym teście na podstawie podtestu Poprawianie zdań, który wymaga od dziecka dostrzeżenia i poprawienia błędów gramatycznych. Znajomość fleksji sprawdza zadanie wymagające deklinowania rzeczowników. Pozostałe podtesty służą badaniu kilku sprawności jednocześnie, np. podtesty Rozumienie bajki i Opowiadanie bajki pozwalają ocenić rozumienie i aktualizowanie nazw, rozumienie i tworzenie zdań, a także rozumienie i budowanie tekstu. Podtesty Zadawanie pytań oraz Prośby i rozkazy badają umiejętność tworzenia aktów mowy w standardowych sytuacjach komunikacyjnych według utrwalonych schematów składniowych.

12. HSET, autorstwa Hannelore Grimm i Hermanna Schölera, został przełożony na język polski przez Marię Przetacznik-Gierowską, Marię Kielar i Agnieszkę Litwę [27].

13. PLAI, autorstwa Marion Blank, Susan Rose i Laury Berlin [28], w Polsce funkcjonuje w przekładzie i adaptacji Marty Białeckiej-Pikul [29].
} 
(czynność - wykonawca - miejsce), tworzenia zdań z podanymi (dwoma lub trzema) słowami oraz stopniowania przymiotników. Oprócz sprawności gramatycznych HSET pozwala ocenić umiejętności komunikacyjne oraz znajomość słownictwa ${ }^{14}$.

Test PLAI mierzy natomiast poznawczą złożoność wypowiedzi na czterech poziomach. Poziom zbierania i kojarzenia doświadczeń oceniany jest na podstawie nazywania, podawania informacji o aktualnych zdarzeniach, zdolności do wyrażania życzeń i pragnień oraz posługiwania się często używanymi zwrotami. Poziom subiektywnej analizy doświadczeń obejmuje próby dotyczące umiejętności relacjonowania o specyficznych właściwościach obiektów, o ich położeniu i funkcjach, a także zdolności do łączenia danych w jedną całość. Na kolejnych poziomach: dotyczącym reorganizacji doświadczeń i dotyczącym wnioskowania na podstawie doświadczeń, dziecko porządkuje doświadczenia w czasie, ustala relacje warunkowe, używa wyrażeń metajęzykowych itp. przy użyciu najbardziej złożonych strukturalnie wypowiedzi. Test różnicuje na poziomie istotnym statystycznie wyniki u dzieci w wieku 4 i 6 lat [23].

Ostatnio opracowane w Instytucie Badań Edukacyjnych narzędzie SNOW służy do oceny dłuższych wypowiedzi dzieci (narracji i renarracji) - jego wyniki mogą być podstawą indywidualnej diagnozy jakościowej przeprowadzonej przez logopedę lub psychologa. W tym samym ośrodku powstało też polskie wystandaryzowane i znormalizowane narzędzie psychometryczne przeznaczone do badania mowy dzieci w wieku 4-8 lat - Test Rozwoju Jezykowego (TRJ) [30]. Badanie obejmuje sześć podtestów w tym trzy dotyczą rozumienia i używania konstrukcji gramatycznych ${ }^{15}$. Poza wynikiem ogólnym TJR analizować można wyniki w obrębie Gramatyki za pomocą odrębnej podskali. W podteście Rozumienie zdań zadaniem dziecka jest wskazanie, który $\mathrm{z}$ prezentowanych obrazków odpowiada treści usłyszanego zdania oznajmującego. Prezentowane zdania są różnej długości (od 3 do 8 słów), przeważają $\mathrm{w}$ nich zdania proste zawierające konstrukcje wyrażające stosunki przestrzenne pomiędzy obiektami (wyrażenia przyimkowe), konstrukcje zawierające dopełniacz atrybutywny (związki rzadu), strone bierna oraz struktury zaimkowe. Podtest Powtarzanie zdań składa się ze zdań do powtórzenia o różnej długości i różnym stopniu złożoności gramatycznej. Wśród zdań pojedynczych występują konstrukcje z czasownikiem modalnym i/lub posiłkowym, zdania w stronie biernej oraz zdania zawierające przeczenie, natomiast wśród zdań złożonych są zdania względne zawierające wyrażenia przyimkowe o różnej frekwencji w języku. Podtest Gramatyka - odmiana wyrazów obejmuje jedynie fleksję rzeczownika. Autorzy, przyjmując założenie, że w wieku lat 4 dzieci mają względnie ustabilizowany system gramatyczny, poddali testowaniu tylko cztery formy przypadkowe, ograniczając tym samym możliwość precyzyjnej oceny stanu sprawności fleksyjnych przez dzieci z zaburzeniami rozwoju sprawności gramatycznej, u których mogą występować zróżnicowane przejawy niedostatku sprawności gramatycznej.

Istniejące narzędzia przeznaczone do oceny stanu sprawności językowych u dzieci w normie i zaburzeniami rozwoju mowy, jakkolwiek zawierają próby odnoszące się do stanu sprawności gramatycznych, nie są wystarczające. Wciąż brakuje technik umożliwiających obiektywne i kompleksowe badanie dzieci w różnych fazach rozwoju, zawierających elementy obejmujące wszystkie kategorie gramatyczne (zarówno fleksyjne, jak i składniowe). Konieczność stworzenia takiego narzędzia z jednej strony wynika z potrzeby rozpoznania dysharmonii lub zaburzeń w rozwoju językowym u dzieci w różnym wieku, z różnymi deficytami rozwojowymi, a $\mathrm{z}$ drugiej strony wiąże się oczekiwaniami dotyczącymi pełnej oceny poziomu rozwoju mowy u dziecka w celu przygotowania programów stymulujących rozwój sprawności gramatycznych.

\section{Badanie rozpadu sprawności gramatycznych}

Zaburzenia gramatyki, obok zaburzeń artykulacji i nominacji, stały się jednym $\mathrm{z}$ najbardziej typowych objawów afatycznej dezintegracji wypowiedzi w związku z uszkodzeniami mózgu w okresie postlingwalnym ${ }^{16}$. Afazjologia poszerzyła lingwistyczne znaczenie terminu „agramatyzm” o dodatkowy aspekt, a mianowicie określenie mechanizmu jego powstawania i związek z uszkodzeniem określonych struktur mózgowych ${ }^{17}$. Kurt Goldstein [35] wyróżnił dwa rodzaje agramatyzmu:

1) agramatyzm myśli, wyrażający się zakłóceniami szyku wypowiedzi,

2) agramatyzm języka, objawiający się trudnościami we właściwym użyciu reguł gramatycznych i niepoprawnym stosowaniu funktorów ${ }^{18}$.

\footnotetext{
14. Badania eksperymentalne przeprowadzone przy użyciu polskiej wersji testu HSET wykazały, że narzędzie to pozwala różnicować na poziomie istotności statystycznej wyniki uzyskane w badaniu dzieci młodszych (w wieku 3 lat) i dzieci starszych (w wieku 4 lat) [31,32] oraz wyniki dzieci pochodzących z różnych środowisk społecznych (ze wsi i wielkiego miasta) [33]. Wykazywane różnice dotyczą zarówno wyniku ogólnego, jak i wyników uzyskiwanych w poszczególnych podtestach. Ponadto wyniki uzyskane w badaniach wysoko korelują z oceną wykonywania zadań do pomiaru rozumienia fałszywych przekonań oraz wynikami badania poziomu funkcji zarządzających.

15. Pozostałe podtesty dotyczą czynnego i biernego zasobu słownika oraz rozumienia słyszanego tekstu.

16. W Słowniku terminologii językoznawczej [34: 21] przy haśle „agramatyzm”, wyjaśnionym jako 'niezdolność do łączenia wyrazów w większe całości składniowe, grupy wyrazowe i zdania', znajduje się odsyłacz do hasła „afazja”.

17. Najwcześniejsze opracowania dotyczące afazji, z początku XX wieku, poświęcone są właśnie afatycznym agramatyzmom. Wymienić należy tu prace m.in. Arnolda Picka „Die agrammatischen Sprachstörungen. Studien zur psychologischen Grundlegung der Aphasielehre” z 1913 roku, Ericha Salomona „Motorische Aphasie mit Agrammatismus und sensorisch-agrammatischen Störungen” z 1914 roku, czy też Maxa Isserlina „Über Agrammatismus” z roku 1922.

18. Joseph M. Wepman zaburzenia językowe dotyczące stosowania reguł gramatycznych, użycia wyrazów funkcyjnych i tworzenia wypowiedzi w „stylu telegraficznym”, występujące przy uszkodzeniach ośrodka Broki, określił mianem „afazji syntaktycznej” [39]. Ten rodzaj objawów odpowiada wyróżnionej przez Romana Jakobsona [40: 166] „afazji kombinacji”, w której chorzy realizują nienacechowane kategorie gramatyczne, używając np. bezokoliczników w miejsce różnych osobowych form czasownika, lub też stosują formę mianownika w miejscu, gdzie należy użyć form deklinacyjnych w przypadkach zależnych. Zaburzenia te tłumaczy Jakobson eliminacją składni zgody i rządu oraz utratą zdolności do dzielenia wyrazów na temat fleksyjny i końcówkę fleksyjną (40: 166).
} 
W pracach Aleksandra R. Łurii [36,37] agramatyzm pojawia się w opisach kilku typów afazji. Mechanizm jego powstawania może wiązać się $\mathrm{z}$ rozpadem ruchowych wzorców wyrazu - tak jest w afazji motorycznej kinetycznej, z utratą lub nietrwałością słuchowych wzorców wyrazu - tak jest w przypadkach afazji akustyczno-gnostycznej i afazji akustyczno-mnestycznej, lub z zakłóceniem syntezy symultatywnej, czyli jednoczesnego przetwarzania wielu informacji, np. dotyczących relacji przestrzennych i czasowych, co występuje w afazji semantycznej. Pierwsze lingwistyczne opisy agramatyzmu w afazji dotyczyły jednak wypowiedzi osób $\mathrm{z}$ afazją motoryczną, dopiero w badaniach afazji na gruncie amerykańskim [38] w obrębie typowych dla tego zaburzenia zjawisk gramatycznych dokonano rozróżnienia, wyodrębniając:

1) agramatyzm motoryczny - na oznaczenie zaburzeń gramatycznych typowych dla afazji non-fluent (motorycznej), kiedy chorzy mówią niepłynnie,

2) paragramatyzm - na oznaczenie zaburzeń gramatycznych typowych dla afazji fluent (sensorycznej), kiedy chorzy mówią płynnie, a zaburzenia składniowe objawiają się redundancją wyrazów w strukturze zdania.

Wyniki prowadzonych analiz odnoszono do sposobu funkcjonowania umysłowych modeli strukturalnych ${ }^{19}$. Sposoby realizowania wzorca gramatycznej struktury zdania w literaturze afazjologicznej opisuje się jako:

- dezintegrację lub zablokowanie wzorca, co znacząco ogranicza możliwość generowania poprawnych gramatycznie i sensownych zdań;

- osłabienie wzorca, kiedy wzorzec składniowy jest aktualizowany prawidłowo $\mathrm{w}$ określonych warunkach albo ulega czasowym odkształceniom pod wpływem uprzednio usłyszanych wypowiedzi;

- modyfikację wzorca:

a) na skutek nieuwzględnienia istotnej cechy wzorca lub cech wzorca, co powoduje, że treść wzorca ulega zawężeniu przy jednoczesnym zwiększeniu zakresu odpowiadających mu treści (błąd abstrakcji pozytywnej);

b) poprzez włączenie dodatkowej nieistotnej cechy lub cech do wzorca, co powoduje wzbogacenie treści i zawężenie jego zakresu (błąd abstrakcji negatywnej) [41,42].
Swoistość struktur składniowych w wypowiedziach osób $\mathrm{z}$ afazją jest wypadkową dwu przeciwstawnych procesów, a mianowicie dezintegracji procesu mówienia oraz strategii kompensacyjnych, służących przełamywaniu zakłóceń w operacjach zdaniotwórczych. Charakter zjawisk składniowych wyznacza, w świetle literatury, granicę między dwoma głównymi rodzajami afazji: w przypadku zaburzeń sensorycznych zachowana pozostaje struktura zdania, jego rusztowanie ${ }^{20}$, natomiast w afazji motorycznej powiązania składniowe ulegają zupełnej dezintegracji.

Składnia pacjentów afatycznych analizowana jest na poziomie powierzchniowym. Jako istotne traktowane są takie elementy, jak: długość zdania, rodzaj związków składniowych występujących w obrębie zdania i wykładniki gramatyczne tych zależności, stosunek składniowy pomiędzy zdaniami składowymi w wypowiedzeniu wielokrotnie złożonym oraz użycie wskaźników zespolenia, częstość występowania i rozkład poszczególnych kategorii wyrazów.

Indeks specyficznych dla chorych $\mathrm{z}$ afazją sposobów realizacji struktur składniowych rysuje się następująco:

1. Wypełnienie wzorca składniowego,

a) potoki składniowe ${ }^{21}$,

b) echolalie ${ }^{22}$,

c) formuliczność wypowiedzeń.

2. Redukcja wzorca składniowego,

a) elipsa składniowa,

b) styl telegraficzny.

3. Rozbudowa wzorca składniowego,

a) ciągi słowne,

b) powtórzenia.

4. Modyfikacja wzorca składniowego,

a) akomodacja składniowa,

b) inwersja składniowa.

5. Kontaminacja wzorca składniowego.

Mechanizm zmian ilościowych i jakościowych w strukturze składniowej wypowiedzi w przypadkach zaburzeń mowy ujmowany bywa w kategoriach zaburzeń programowania wypowiedzi i opisywany jest jako skutek działania trzech osobnych procesów:

1. przestawienia (transpozycji),

\footnotetext{
19. Niektóre zjawiska w mowie chorych z afazją można trafniej zinterpretować, odwołując się do modeli kognitywnych, szczególnie gramatyki generatywno-transformacyjnej. Chociaż w tekstach afatycznych obserwuje się trudności w realizacji struktur powierzchniowych, to łatwo daje się odczytać sens wypowiedzeń poprzez odwołanie się do struktur głębokich. Widać to szczególnie wyraźnie na przykładzie licznych kontaminacji składniowych struktur powierzchniowych, które opisywane były dotychczas jako przejawy dezintegracji wzorca składniowego, a zaburzenia łączliwości gramatycznej wyrazu były podstawą orzekania o agramatyzmie w afazji [43].

20. Z badań R. Jakobsona wynika, że struktury składniowe osób z zakłóceniami w dziedzinie podobieństwa (afazją sensoryczną) przejawiają się zaburzeniem składniowego kontekstu. Występuje tendencja do opuszczania głównego, porządkującego członu zdania - podmiotu, podczas gdy wyrazy porządkowane przez składnię zgody lub rządu są bardziej odporne na rozpad. Zapoczątkowanie wypowiedzi, a z tym wiąże się w neutralnym szyku języka polskiego użycie podmiotu, stanowi dla osób z afazją sensoryczną główną trudność. Jednakże znaczenie tak zakłóconych struktur można zdekodować poprzez odwołanie się do poprzednich zdań (pomyślanych lub wypowiedzianych przez nadawcę lub/i odbiorcę). Szczególnie trwałe w tym typie zaburzeń okazują się wyrazy, które mogą odnosić się do kontekstu (zaimki), lub wyrazy tworzące kontekst (partykuły) [40: 158].

21. W lingwistyce za potok składniowy uznaje się „ciąg wyrazów i wyrażeń luźno ze sobą powiązanych, nieuporządkowanych ani logicznie, ani syntaktycznie. W ciągu takim, w miarę nasuwających się myśli lub stanów uczuciowych, nastẹpują wyrazy i człony syntaktyczne wiążące się ze sobą tylko zewnętrznie. Powiązanie stanowi ogólna myśl bądź intencja mówiącego, nie jest jednak ona do tego stopnia porządkująca, żeby mogła z góry narzucić wypowiedzi schemat logiczny” [44: 240].

22. Echolalia (gr. echo 'dźwięk, echo' i lalia 'gadanina') polega na powtarzaniu jednakowych lub podobnych układów głoskowych. Zjawisko to występuje często w mowie dzieci oraz w wypowiedziach osób z zaburzeniami psychicznymi, gdzie jest objawem automatycznych, niezamierzonych i nonsensownych zachowań. W afazji, zwłaszcza motorycznej, echolalia jest strategią przystosowawczą i kompensującą znaczne trudności w formułowaniu zdań. Mimowolne powtarzanie jest symptomatyczne przede wszystkim dla afazji motorycznej dynamicznej, ale pojawia się także w afazji motorycznej kinetycznej lub afazji mieszanej (motoryczno-sensorycznej) [43].
} 
2. wyprzedzenia (antycypacji),

3. powtórzenia (perseweracji).

Najczęściej zaburzenie gramatycznej struktury zdania wiąże się z naruszaniem związków gramatycznych: związków zgody pod względem liczby, rodzaju, przypadka, redukcją obligatoryjnych części schematu składniowego lub też nadmiernym jego rozwinięciem. Jednakże pozycja wyrazów w zdaniu, obecność relewantnych, ze względu na informacyjność wypowiedzeń, części wzorca składniowego, realizacja przebiegów melodycznych, a przede wszystkim językowy i pozajęzykowy kontekst sprawiają, że pomimo naruszenia powierzchniowej spójności gramatycznej i semantycznej, większość wypowiedzi realizuje założone przez mówiącego funkcje pragmatyczne.

Zaburzenia systemu gramatycznego w afazji są wyjaśniane jako neutralizacja (zniesienie) fleksji lub jako niedostatek elementów pełniących w zdaniu funkcje gramatyczne, a przez to niewłaściwe posługiwanie się morfemami gramatycznymi i zniekształcenia tych morfemów oraz wszelkie zakłócenia poprawności zdań. Przyjęcie założenia o neutralizacji (łac. neutralis 'nijaki, niczyj'; neutrum 'nijakie') morfemów fleksyjnych każe eksponować $\mathrm{w}$ ocenie gramatyki wypowiedzi chorych $\mathrm{z}$ afazją przejawy redukcji funkcjonalnych opozycji pomiędzy różnymi kategoriami gramatycznymi, zniesienie gramatycznego nacechowania wyrazów odmiennych i skłonność do tworzenia form podstawowych wyrazów. Przyjęcie hipotezy o rozchwianiu systemu gramatycznego [39] implikuje ujmowanie w opisie wszelkich przejawów gramatycznego nacechowania wypowiedzi osób z afazją. Taka analiza doprowadza do wniosku, że chorzy są w stanie realizować wszystkie morfemy fleksyjne istniejące w języku polskim, ale stosują je w niewłaściwych kontekstach, wymiennie $\mathrm{z}$ formami prawidłowymi. Innym spostrzeżeniem płynącym $z$ badań jest stwierdzenie występowania tych samych mechanizmów powodujących powstawanie agramatyzmów u chorych z zaburzeniami motorycznymi i sensorycznymi, a są nimi: zniekształcenia fonetycznej postaci morfemów („mechanizm fonetyczny”) $[39,45]$ oraz zakłócenia w dystrybucji jednostek systemu fleksyjnego („mechanizm systemowy”).

W dotychczasowych opisach zjawisk gramatycznych w afazji przeważa koncepcja deficytu językowego, czyli utraty sprawności gramatycznych. Stąd wszelkie zaburzenia w realizacji systemu fleksyjnego języka określa się mianem „agramatyzmu”, czyli braku tych elementów językowych, które wyrażają wzajemne ustosunkowanie składników w zdaniu ${ }^{23}$. Rzeczywiście, charakterystyka składniowa wypowiedzi osób z nabytymi zaburzeniami mowy w przebiegu schorzeń neurologicznych ujawnia niedobór rozbudowanych zdań pojedynczych, brak rozbudowanych grup nominalnych, nieobecność imiesłowowych struktur składniowych, niedostatek zdań podrzędnie złożonych orzecznikowych, okolicznikowych miejsca przy zatarciu formalnych sygnałów podrzędności w innych parataksach, ograniczenie konstrukcji analitycznych, pomijanie silnie konotowanych członów zdania, naruszenie ciągłości związków bezpośrednich miedzy częściami zdania, z drugiej zaś strony wykazuje wysoką częstotliwość równoważników zdań, wypowiedzeń eliptycznych, potoków składniowych, wyrazów i wyrażeń luźno ze sobą powiązanych, znaczną frekwencję struktur zakłócających regularny tok składniowy (wtrąceń, zdań urwanych, anakolutów składniowych), a także oznajmień i wykrzyknień, bogactwo i duże zróżnicowanie wypowiedzeń modalnych, performatywnych oraz formul fatycznych [43].

Badania rozpadu systemu gramatycznego nie są kompleksowe. Najwięcej uwagi poświęca się rzeczownikom. Dla pełnego opisu zaburzeń w podsystemie morfologicznym języka konieczne są dokładne badania zarówno poszczególnych kategorii fleksyjnych odmiennych części mowy w ich pełnych paradygmatach deklinacyjnych i koniugacyjnych, związków składniowych pomiędzy wyrazami, a także składniową złożoność wypowiedzi. Precyzyjną ocenę składni tekstów afatycznych uniemożliwia niedostateczne opracowanie charakterystyki tego podsystemu w odniesieniu do języka potocznego oraz niedostatek prób do badania sprawności gramatycznych w narzędziach służących diagnozowaniu nabytych zaburzeń językowych.

Wielowymiarowe baterie do oceny nabytych zaburzeń językowych u osób chorych neurologicznie powstawały najczęściej na gruncie innego systemu językowego ${ }^{24}$, w odmiennych uwarunkowaniach społeczno-kulturowych. Próby adaptacji tych narzędzi do specyfiki polskiego systemu językowego i polskich norm kulturowych są zawsze trudne, zwłaszcza w kontekście standaryzacji wyników ilościowych w związku z fleksją - specyficzną i bogatą w języku polskim. Ocena sprawności tak bardzo złożonych, jak zdolność do rozumienia i tworzenia konstrukcji gramatycznych, z trudem poddaje się normalizacji również w warunkach jednej narodowości, przede wszystkim ze względu na wysoki stopień zróżnicowania jednostkowych zachowań językowych uwarunkowany społeczną charakterystyką badanych. Istnieją co prawda specjalne narzędzia do oceny rozumienia struktur językowych o różnym stopniu komplikacji gramatycznej i semantycznej, np. The Token Test [50], znany w Polsce jako Test Żetonów [51] wraz z jego modyfikacjami [52], jednak nie obejmują one wszystkich aspektów gramatycznych koniecznych do precyzyjnej oceny poziomu rozumienia i tworzenia struktur gramatycznych.

\footnotetext{
23. Analizy wypowiedzi afatycznych wykazują, że kontekst pojawiania się agramatyzmów może być rozmaity. Częściej występują agramatyzmy w tym otoczeniu, które jednoznacznie implikuje gramatyczne funkcje użytej nieprawidłowo konstrukcji, rzadziej spotyka się je w kontekstach obligatoryjnych, na przykład forma bezokolicznika jest prawidłowo realizowana w zdaniach bezokolicznikowych, szyk wyrazów uwzględnia kanoniczną składnię zdania, czasownik niegramatycznie użyty nigdy nie jest traktowany jak rzeczownik (w języku niemieckim nie poprzedzają go rodzajniki). Takie spostrzeżenie nasuwa wniosek o zdolności chorych z afazją do realizacji tekstu komunikatywnego przy redukcji redundantnych struktur języka. Afatyczne agramatyzmy mają selektywny charakter, uzależniony od stopnia relewancji gramatycznych wykładników funkcji i znaczenia wyrazów tekstowych [43].

24. Por. The Boston Diagnostic Aphasia Examination (BDAE - Bostoński Test Diagnostyczny do Badania Afazji) [46], The Minnesota Test for the Diferential Diagnosis of Aphasia (MTDDA - Minnesocki Test do Diagnozy Różnicowej Afazji) [47], Multilingual Aphasia Examination (MAE - Wieloaspektowe Badanie Funkcji Językowych w Afazji) [48], Aachner Aphasie Test (AAT - Bateria Diagnostyki Afazji Aachen) [49].
} 
W postępowaniu diagnostycznym ocenę sprawności gramatycznych przeprowadza się przez analizę spontanicznych wypowiedzi pacjenta lub stosuje się próby eksperymentalno-kliniczne badające np. poprawność form fleksyjnych wyrazów, które są uzupełnieniem brakujących elementów w zdaniu, zdolność do konwersji jednej struktury gramatycznej na inną według określonej reguły itp. ${ }^{25}$. Istnieją też niestandaryzowane narzędzia do badania nabytych zaburzeń językowych, np. Próby do oceny zaburzeń poznawczych u pacjentów z uszkodzeniami mózgu [53], Badanie afazji [54] czy Skala do Oceny Dynamiki Zaburzeń Afatycznych SODA [55], obejmujące m.in. standardowe próby pozwalające ocenić rozumienie struktur gramatycznych na podstawie wykonywania poleceń prostych (np. Proszę zamknać oczy) i złożonych (np. Proszę podnieść rękę i zamknać oczy), poleceń wymagających rozumienia konstrukcji fleksyjnych (np. Proszę kluczem pokazać kartkę). Tworzenie konstrukcji przyimkowych ocenia się zwykle w zadaniach z użyciem materiału ilustracyjnego.

Badania rozpadu systemu gramatycznego wciąż nie są kompleksowe. Dla pełnego opisu zaburzeń w podsystemie morfologicznym języka konieczne są narzędzia do dokładnej oceny poszczególnych kategorii fleksyjnych, związków składniowych i zdań o różnej organizacji strukturalnej.

\section{Wnioski}

Sprawność gramatyczna ma charakter systemowy, dlatego jej diagnozowanie i usprawnianie powinno odwoływać się do reguł systemu językowego. Badanie sprawności systemowych powinno obejmować ocenę paradygmatów fleksyjnych we wszystkich kategoriach koniugacyjnych i deklinacyjnych oraz dynamicznych modeli składniowych. Jedynie kompletna ocena sprawności gramatycznych może być podstawą do planowania terapii logopedycznej ukierunkowanej na przełamanie rozpoznanych deficytów gramatycznych.

Narzędzie do badania sprawności gramatycznej powinno zatem obejmować: 1) rozumienie i tworzenie: gramatycznej kategorii czasu - służącej określaniu relacji między zdaniem a współrzędnymi ustalonymi przez akt mówienia, gramatycznej kategorii aspektu - wyrażającej subiektywne różnice w sposobie ujmowania rzeczywistości pozajęzykowej, gramatycznej kategorii trybu - morfologicznego środka do wyrażania modalności, gramatycznej kategorii strony - wyrażającej stosunek między podmiotem i dopełnieniem a orzeczeniem zdania, gramatycznej kategorii osoby - służącej aktualizacji wypowiedzenia poprzez odniesienie sytuacji stanowiącej treść tego wypowiedzenia do okoliczności aktu mówienia, gramatycznej kategorii przypadka - służącej sygnalizowaniu funkcji syntaktycznej spełnianej w wyrażeniu zdaniowym przez daną grupę imienną, a wewnątrz grupy imiennej wskazującej na zależności gramatyczne pomiędzy członami grupy, oraz gramatycznej kategorii rodzaju - właściwej wszystkim odmiennym częściom mowy (rzeczownikom, zaimkom, liczebnikom, przymiotnikom i czasownikom, 2) rozumienie i tworzenie form imiesłowowych i form gradacyjnych przymiotników i przysłówków, 3) rozumienie i tworzenie składniowych związków zgody, rządu i przynależności, 4) rozumienie i tworzenie struktur składniowych powiązanych para- i hipotaktycznie o zróżnicowanym stopniu składniowej komplikacji.

Ponadto narzędzia metryczne stosowane w diagnozie logopedycznej powinny uwzględniać występowanie zmienności objawów zaburzeń gramatycznych w związku z czynnikiem czasu i minimalizować wpływ środowiska, inteligencji, wykształcenia oraz pamięci na ocenę zaburzeń językowych. Interpretacja danych testowych powinna różnicować osoby zdrowe, osoby z zaburzeniami mowy oraz osoby bez zaburzeń językowych, ale z objawami innych zaburzeń poznawczych. Narzędzia do oceny rozwoju sprawności gramatycznych w ontogenezie i do badania rozpadu tych sprawności u osób w okresie postlingwalnym na potrzeby diagnozy i terapii logopedycznej wciąż czekają na opracowanie.

Artykuł powstat $w$ związku $z$ realizacja projektu „Zintegrowany system narzędzi do diagnostyki i telerehabilitacji schorzeń narzqdów zmysłów (słuchu, wzroku, mowy, równowagi, smaku, powonienia)" wspólfinansowanego przez Narodowe Centrum Badań i Rozwoju w ramach Programu STRATEGMED.

\section{Piśmiennictwo:}

1. Grabias S. Język w zachowaniach społecznych. Lublin: Wydawnictwo UMCS; 1997.

2. Grabias S. Mowa i jej zaburzenia. Audiofonologia, 1997; 10: 9-36.

3. Grzegorczykowa R, Laskowski R, Wróbel H, red. Gramatyka współczesnego języka polskiego. Morfologia. Warszawa: PWN; 1998.

4. Grabias S. Minimalizacja systemu językowego dla potrzeb glottodydaktyki i logopedii. W: Opuscula Logopaedica in honorem Leonis Kaczmarek. Lublin: Wydawnictwo UMCS; 1993: $48-56$.

5. Grzegorczykowa R. Wykłady z polskiej składni. Warszawa: PWN; 1998.
6. Saloni Z, Świdziński M. Składnia współczesnego języka polskiego. Warszawa: PWN; 1985.

7. Kurcz I. Język a reprezentacja świata w umyśle. Warszawa: PWN; 1987.

8. Kurcz I. Język a psychologia. Podstawy psycholingwistyki. Warszawa: WSiP; 1992.

9. Żmigrodzki P. Związki między składnikami w zdaniu. W: Achtelik A, Tambor J, red. Sztuka czy rzemiosło? Nauczyć Polski i polskiego. Katowice: Gnome; 2007, 35-51.

10. Klemensiewicz Z. O tzw. przejęzyczeniach. Język Polski, 1959; 39: 173-80.

11. Saussure de F. Kurs językoznawstwa ogólnego. Warszawa: PWN; 1991.

\footnotetext{
25. Należy przy tym zaznaczyć, że zakłócenia form fleksyjnych w afazji mogą być wtórnie wywołane błędną artykulacją (agramatyzmy słuchowe i ruchowe) [45]. W polskiej literaturze przedmiotu istnieje monografia na temat agramatyzmu w afazji autorstwa Hanny Tomaszewskiej-Volovici [39].
} 
12. Chomsky N. Zagadnienia teorii składni. Wrocław: Zakład Narodowy im. Ossolińskich; 1982.

13. Parol UZ. Dziecko z niedokształceniem mowy. Warszawa: WSiP; 1989.

14. Panasiuk J. Postępowanie logopedyczne w przypadkach alalii i niedokształcenia mowy o typie afazji. W: Grabias S, Panasiuk J. Woźniak T, red. Logopedia. Standardy postępowania logopedycznego. Lublin: Wydawnictwo UMCS; 2015, 309-45.

15. Emiluta-Rozya D, Mierzejewska H, Atys P. Badanie przesiewowe do wykrywania zaburzeń mowy u dzieci dwu-, czteroi sześcioletnich. Warszawa: Wydawnictwo ASP; 2004.

16. Paluch A, Drewniak-Wołosz E, Mikosza L. Afa-skala. Jak badać mowę dziecka afatycznego. Kraków: Impuls; 2002.

17. Michalak-Widera I, Węsierska K. Test do badań przesiewowych mowy dzieci w wieku przedszkolnym. Katowice: Unikat 2; 2012.

18. Emiluta-Rozya D. Całościowe badanie logopedyczne z materiałem obrazkowym. Warszawa: Wydawnictwo ASP; 2013.

19. Niemierko B. Diagnostyka edukacyjna. Podręcznik akademicki. Warszawa: PWN; 2000.

20. Pickstone C, Hannon P, Fox L. Surveying and screening preschool language development in community-focused intervention programmes: a reviev of instruments. Child: Care, Heath and Development, 2002; 28: 251-64.

21. Tarkowski Z. Przesiewowy Test Logopedyczny. Lublin: Wydawnictwo Orator; 2002.

22. Grabias S, Kurkowski ZM, Woźniak T. Logopedyczny Test Przesiewowy dla dzieci w wieku szkolnym. Lublin: Wydawnictwo PTL; 2002.

23. Kielar-Turska M. Testy sprawności językowych i komunikacyjnych w diagnozie logopedycznej. W: Milewski S, Kaczorowska-Bray K, red. Metodologia badań logopedycznych z perspektywy teorii i praktyki. Gdańsk: Wydawnictwo Harmonia; 2015: 213-27.

24. Wojtowicz M. Test Zdolności Językowych. Warszawa: Pracownia Testów Psychologicznych PTP; 2006.

25. Tarkowski Z. Test sprawności językowej. Lublin: Wydawnictwo Orator; 2000

26. Smoczyńska M, Haman E, Czaplewska E, Maryniak A, Krajewski G, Banasik N i wsp. Standaryzowane Narzędzie do Oceny Wypowiedzi (SNOW), Warszawa: Instytut Badań Edukacyjnych; 2015.

27. Przetacznik-Gierowska M, Kielar M, Litwa A. Test sprawności językowych. Polska adaptacja testu HSET (Heidelberger Sprachentwicklungstest). Kraków: Instytut Psychologii UJ; 1978.

28. Blank B, Rose S, Berlin L. Preschool Language Assesment Instrument: The Language of learning in practice. USA: Psychological Corporation; 1978.

29. Białecka-Pikul M. Polska wersja testu PLAI (Preschool Language Assessment Instrument) do badania kompetencji komunikacyjnej dzieci przedszkolnych. Kwartalnik Polskiej Psychologii Rozwojowej, 1994; 4(1): 127-50.

30. Smoczyńska M, Haman E, Czaplewska E, Maryniak A, Krajewski G, Banasik N, Kochańska M, Łuniewska M, Morstin M. Test Rozwoju Językowego (TRJ). Warszawa: Instytut Badań Edukacyjnych; 2015.

31. Kielar-Turska M. Rozwój sprawności językowych i komunikacyjnych. W: Czaplewska E, Milewski S, red. Diagnoza logopedyczna. Sopot: Gdańskie Wydawnictwo Psychologiczne; 2012, $15-63$.
32. Kielar-Turska M. Sprawności językowe i komunikacyjne a inne funkcje psychiczne. W: Milewski S, Kaczorowska-Bray K, red. Logopedia. Wybrane aspekty historii, teorii i praktyki. Gdańsk: Wydawnictwo Harmonia; 2012, 70-86.

33. Kielar M. Sprawność językowa dzieci wiejskich u progu szkoły. W: Kielar M, Radochoński M, red. Rozwój i wychowanie dziecka wiejskiego. Rzeszów: Wydawnictwo WSP w Rzeszowie; 1989, 191-203.

34. Gołąb Z, Heinz A, Polański K. Słownik terminologii językoznawczej. Warszawa: PWN; 1968.

35. Goldstein K. Language and Language Disturbances. New York: Ronald Press; 1948.

36. Łuria AR. Zaburzenia wyższych czynności korowych wskutek ogniskowych uszkodzeń mózgu. Warszawa: PWN; 1967.

37. Łuria AR. Problemy psychologii i neurolingwistyki. Warszawa: PWN; 1976.

38. Wepman J, Jones L. Studies in Aphasia. An Approach to Testing. Chicago: University of Chicago Education, Industry Service; 1961.

39. Tomaszewska-Volovici H. Agramatyzm w afazji (na materiale polskim). Wrocław: Zakład Narodowy im. Ossolińskich; 1976.

40. Jakobson R. W poszukiwaniu istoty języka. Wybór pism. Mayenowa MR, red. Warszawa: PIW; 1989.

41. Lewicki AM. Słownik a gramatyka w leksykograficznym opisie związków gramatycznych. W: Basaj M, red. Typy opisów gramatycznych języka. Wrocław: Zakład Narodowy im. Ossolińskich; 1986: 157-70.

42. Mierzejewska $\mathrm{H}$, red. Badania lingwistyczne nad afazją. Wrocław: Zakład Narodowy im. Ossolińskich; 1978.

43. Panasiuk J. Realizacja struktur składniowych w afazji. Logopedia, 2003; 32: 15-61.

44. Kurkowska H, Skorupka S. Stylistyka polska. Zarys. Warszawa: PWN; 1966.

45. Goodglass H. Studies on the grammar of aphasics. W: Goodglass $\mathrm{H}$, red. Psycholinguistics and aphasia. Baltimore: Johns Hopkins University Press; 1973.

46. Goodglass H, Kaplan E. Boston Diagnostic Aphasia Examination. Philadelphia: Psychological Corporation; 1972.

47. Schuell H. Administrative Manual for the Minnesota Test for Differential Diagnosis of Aphasia. Minneapolis: University of Minnesota Press; 1965.

48. Benton AL, Hamsher K, Sivan AB. Multilingual Aphasia Examination. Iowa City: AJA Associates; 1978.

49. Huber W, Poeck K, Weniger D, Wilmes K. Der Aachner Aphasie Test (AAT). Göttingen: Hogrefe; 1983.

50. De Renzi E, Vignolo LA. The Token Test: a Sensitive Test To Detect Receptive Disturbances in Aphasia. Brain, 1962; 85(4): 665-78.

51. Kościesza M. Wartość diagnostyczna Token Testu w badaniu zaburzeń afatycznych. Audiofonologia, 1990; 2: 71-84.

52. Orgass B. Eine Revision des Token Tests. Teil I und II. Diagnostica, 1976; 22: 70-87, 141-56.

53. Łucki W. Zestaw prób do badania procesów poznawczych u pacjentów z uszkodzeniami mózgu. Warszawa: Pracownia Testów Psychologicznych; 1995.

54. Szumska J. Metody badania afazji. Warszawa: PZWL; 1980.

55. Puchowska-Florek M, Książkiewicz B, Nowaczewska M. Ocena przydatności wybranych skal i testów do oceny afazji u pacjentów w ostrym okresie udaru mózgu. Udar Mózgu, 2005; 7(2): 39-47. 